\title{
The Loyal Son: The War in Ben Franklin's House
}

Daniel Mark Epstein

New York: Ballantine Books, 2018

440 pages including illustrations, acknowledgments, sources and notes, and index

ISBN: 9780345544230

DOI: http://dx.doi.org/10.14713/njs.v4i2.138

Both the title and preface of this book are provocative. First, many Americans know that Benjamin Franklin was an author, newspaper editor, scientist, diplomat, and patriot who signed both the Declaration of Independence and the U.S. Constitution. Far fewer realize that his illegitimate son William Franklin, sometimes remembered for helping with the kite experiment that proved lightening was electricity, was a soldier, lawyer, and the last royal governor of colonial New Jersey. He was then a prisoner of war in Connecticut, then an active leader in New York City of the Associated Loyalists. He ended his life an exile in England. This son was a Loyalist who sided with the British during the Revolution and after, but the author also argues that he was loyal to his father, and devoted to the entire Franklin family before, during, and after the Revolution. While trying to balance father and son against one another, and chronicle how the war divided them, Epstein is also trying to rehabilitate the governor's reputation. In doing so he tends to put the father in the more unfavorable light.

Second, the preface gets the book off on a discordant note because most historians carefully distinguish between fact and fiction (highly relevant in today's world). Yet the brief preface is an admitted fictional account of the circumstances of William's birth, and who his mother was, even as the author notes there are no records about it. He imagines a young Benjamin taking the infant from his tearful birth mother, and home to his wife Deborah who accepted and helped raise the child. Later speculation and discussion of the successive illegitimate births in this line of the Franklin family are more clearly documented. This becomes a fascinating story as in three 
generations, Benjamin's son, grandson, and great granddaughter, all illegitimate children, were acknowledged and raised by family members.

When the author gets going, he tells a story not only about the close ties of the two men in Pennsylvania politics and then London, but also the ways in which the Revolution was a complex Civil War that tore some families apart. In the end, as his actions and the contents of his will proved, Benjamin could not forgive his son for "The part he acted against me in the late war." After the father's death, William reconciled with his son, William Temple Franklin, and his sister, Sally Franklin Bache, and her family. Shortly before the Peace Treaty she had written Temple, "I should despise the person who could not make a distinction between political difference and a family one." They later visited England, but returning to New Jersey or elsewhere in the new United States was not an option for the former governor.

In describing the Revolution, Epstein falls into the pattern of recent historiography that presents a dark view of the ways in which this was a nasty bitter war, certainly an apt description for much of New Jersey. William was caught up in it, spending time in a "Litchfield jail, the rats, the reeking bed of straw, and nearly a year in solitary confinement." While confined there his wife died. After being exchanged for a patriot governor, he sent raiders off to attack patriots in New York, New Jersey, and Connecticut. It was his group that summarily hung militia leader Joseph Huddy, provoking Washington to threaten to execute a captured British officer in retaliation. Epstein calls both sides "terrorists," a modern term; they certainly took extreme actions.

In writing about William and other loyalists, he joins a recent spate of works on the topic. While comparing the two Franklin men he expands on the short book by Sheila Skemp, Benjamin and William Franklin: Father and Son, Patriot and Loyalist (1994), that briefly did the same. Although she was concerned with why they took different sides, he is more interested in why 
reconciliation was not possible. While much has been written about Benjamin Franklin, this is not true of his son. There are short pieces, including an entry in the book on New Jersey's governors, and Sheila Skemp's longer Benjamin and William Franklin: Son of a Patriot, Servant of a King (1990), which is the most scholarly work on the governor. While Epstein has done a considerable amount of research, and turned up some documents not previously used, what he adds is a poet's sense of language (he has published more works of poetry than history). He describes a mid-June 1775 meeting of the two Franklins, and their conservative friend Joseph Galloway, as taking place "as the crickets and tree frogs trilled through open windows" while "a great deal of liquor was consumed" but no agreement was reached. The "acknowledgments" are really a short essay on sources, the footnotes are brief, and confined to citing quotations. That noted, this is an easy and interesting book to read; while scholars should look at it, it surely will attract a general audience, and in the process make more people aware of the role New Jersey played in the Revolution.

\section{Maxine N. Lurie Seton Hall University}

